\title{
NOTICIÁRIO
}

\section{CNPq ESCOLHE GANHADORES DO PRÊMIO JOSÉ REIS 1990}

A Comissão Julgadora, composta de representantes da comunidade científica e da Imprensa, escolheu os ganhadores do Prêmio José Reis de Divulgação Científica referente a 1990. O Prêmio, criado e mantido pelo CNPq - Conselho Nacional de Desenvolvimento Científico e Tecnológico, reconhece o trabalho de jornalistas, instituições e pesquisadores que se destacam na tarefa de divulgar para o público leigo aspectos da Ciência e Tecnologia.

Na modalidade jornalismo, o ganhador foi Ricardo Bonalume Neto, repórter do Jomal Folha de São Paulo, integrante da equipe do Caderno Ciência. Bonalume Neto é também editor da Revista Nova-ciência e correspondente no Brasil para a seção de notícias da revista científica Nature, editada na Inglaterra.

Ricardo Bonalume Neto nasceu em 1960, em São Paulo e formoù-se em Jornalismo em 1982 pela Escola de Comunicações e Artes da USP. Ingressou na Folha de São Paulo em 1985. Integra a editoria responsável pela edição do Caderno Ciência desde o surgimento deste suplemento, em março de 1989. Em seu currículo inclui um estágio de seis meses no jornal The Atlanta Constitution e na revista U.S. News e World Report.

Na modalidade instituição, o Prêmio José Reis foi concedido à revista Superinteressante, da Editora Abril. A Revista, lançada em novembro de 1987, tem hoje uma circulação paga de $400 \mathrm{mil}$ exemplares mensais (média de $380 \mathrm{mil} \mathrm{em} \mathrm{1990),}$ dos quais 250 mil são assinaturas. É a segunda revista brasileira em circulação, só superada pela revista Veja, também da Editora Abril. A proposta editorial da Revista Superinteressante é divulgar a ciência, a tecnologia, a cultura e denunciar o misticismo, a crendice, a falsa ciência.

Na modalidade divulgação científica, a ganhadora é Virginia Torres Schall, pesquisadora do Departamento de Biologia da Fundação Instituto Oswaldo Cruz (Rio de Janeiro). Ao lado de sua atuação como cientista, Virginia escreveu seis livros de literatura infantil entre 1984 e 1990 . Os livros tratam de questões de saúde que afetam as crianças brasileiras. A ganhadora na categoria divulgação científica é autora de um jogo denominado Zig-Zaids, que objetiva a esclarecer dúvidas de pré-adolecentes sobre a AIDS. O jogo está sendo lançado por uma editora do Rio de Janeiro, em quatro idiomas (português, espanhol, inglês e francês), para atender outros países que já demonstram interesse pela proposta de divulgação educativa. Os ganhadores nas categorias jornalismo e divulgação científica receberão, cada um, o equivalente a 100 MVR (Cr\$226 mil cruzeiros em abril). Na categoria instituição, o contemplado recebe apenas medalha e diploma. O Prêmio José Reis de Divulgação Científica referente a 1990 será entregue em junho, em local que será oportunamente divulgado pelo $\mathrm{CNPq}$.

\section{PRÊMIO HOMENAGEIA DECANO DA DIVULGAÇÃO CIENTÍFICA NO BRASIL}

O Prêmio José Reis de Divulgação Científica foi criado em 1978 pelo CNPq - Conselho Nacional de Desenvolvimento Científico e Tecnológico. Ao dar ao Prêmio o nome de José Reis a intenção foi homenagear aquele que é considerado o decano da divulgação científica no Brasil, o cientista e jornalista José Reis que mantém, há 42 anos ininterruptos, uma seção semanal sobre ciência no Jornal Folha de S. Paulo.

A partir de 1982 o Prêmio José Reis passou a ser concedido anualmente. Desde 1983, há premiação em três modalidades. Em Divulgação Científica concorrem cientistas, pesquisadores e divulgadores da ciência. A modalidade Jornalismo Científico só permite a participação de jornalistas profissionais. $\mathrm{Na}$ modalidade Instituição podem concorrer organismos como museus, centros de pesquisa e, também, veículos de comunicação.

A intenção do Prêmio é incentivar e reconhecer o trabalho realizado no sentido de fazer chegar ao público mais amplo possível informações sobre aspectos da Ciência e da Tecnologia. Já receberam o Prêmio, dentre outros, o cientista Oswaldo Frota Pessoa, a revista Ciência Hoje, editada pela Sociedade Brasileira para o Progresso da Ciência, a educadora Maria Julieta Sebastiani Ormastroni, o jornalista Ethevaldo Mello de Siqueira e o médico e jornalista Júlio Abramczyk. 